\title{
Spatial Variations in the Role of Microenterprises in Economic Growth*
}

\author{
Steven C. Deller ${ }^{+}$
}

\begin{abstract}
Using U.S. county data from 1990 and 2000, a family of spatial models examining growth in population and employment are reported. Special attention is paid to the role of microenterprises-firms with less than five employees - in predicting economic growth. Results suggest that microenterprises play an important but complex role in economic growth. Depending on the industry classification of the microenterprises, and coupled with the metric of growth, there is significant heterogeneity in the policy implications of microenterprises and economic growth. Policy implications are that blanket statements about how small businesses influence growth can be misleading. Spatial heterogeneity in the determinants of economic growth using Geographically Weighted Regression (GWR) is also examined. These results provide strong evidence supporting the idea that there is significant spatial variation and that policies must be crafted to fit specific regional needs.
\end{abstract}

Keywords: entrepreneurship, economic growth, growth policy

JEL Classification Codes: R11, L25, C21

\section{INTRODUCTION}

The role of small businesses in economic growth and development has been the focal point of a range of studies over the past 30 years (Aquilina, Klump, and Pietrobelli, 2006). Birch's $(1979,1987)$ argument that small businesses are particularly important in generating job growth, coopted by the Small Business Administration (SBA) $(1983,1987)$, has renewed interest in the idea of Schumpeter's $(1942,1961)$ innovative entrepreneur in the economic growth process. As outlined by Shaffer, Deller, and Marcouiller (2006), renewed interest in small businesses has been the backbone of the "Second Wave" of economic development policies (c.f., Acs, 1999; Blair, 1999; Olberging, 2002; Bradshaw and Blakely, 1999; Eisinger, 1988, 1995; Muske and Woods, 2004). Here local economic development efforts focus not only on the retention and expansion of existing businesses but also the promotion of entrepreneurship and small business development.

Within the academic literature, the work of Birch and the SBA has been widely challenged with critiques ranging from the viability of the primary dataset (Dun and Bradstreet; an extremely powerful dataset but not one designed or maintained to strategically study job creation and destruction) to basic methodological approaches, (e.g., Brown, Hamilton, and Medoff, 1990; Davis, Haltiwanger, and Schuh, 1994, 1996; Dunne, Roberts, and Samuelson, 1989; Haltiwanger and Krizan, 1999). The work of Birch, the SBA and more recently Zoltan Acs and David Audretsch and their colleagues set the stage for a number of studies that have examined the role of small businesses within a regional growth context (e.g., Deller and McConnon, 2009; Loveridge and Nizalov, 2007; Shaffer, 2002, 2006).

\footnotetext{
* Support for this work was provided in part by the University of Wisconsin Agricultural Experiment Station under the Hatch Act. All errors are the author's.

${ }^{+}$Deller is Professor in the Department of Agricultural and Applied Economics, University of Wisconsin-Madison/Extension, 515 Taylor Hall, 427 Lorch Street, Madison, WI 53706.E-mail: scdeller@wisc.edu.

C Southern Regional Science Association 2011.

ISSN 1553-089

SRSA, 1601 University Avenue, PO Box 6025, Morgantown, West Virginia 26506-6025, USA.
} 
This work has proceeded along two very distinct lines. Studies aimed at replicating and improving the work of Birch and the SBA have tended to be micro-oriented, tracing individual firms over the long-term while the regional work tends to use macro data to look at city, metro or state level. ${ }^{1}$ This study falls into the second category, as it looks at growth patterns across U.S. counties. In the broadest sense, the regionally focused work has attempted to build a stronger theoretical foundation by appealing to well-developed regional growth theory, as well as strengthen the empirical foundation for economic development practitioners at the local level who focus their efforts on small business development.

Beck, Demirgüç-Kunt, and Levine (2003) along with Aquilina, Klump, and Pietrobelli (2006); Shaffer (2006); and Loveridge and Nizalov (2007) lay out the rationale, both pro and con, for the promotion of small businesses, especially microenterprises as an economic development strategy. Advocates argue that small businesses stimulate competition and entrepreneurship which, in turn, enhances efficiency, innovation, and aggregate productivity growth. Acs and Audretsch $(1990,1993)$ maintain that in manufacturing the development of small-scale, flexible production technologies has enabled small firms to flourish. Because of the small scale of operation, microenterprises are more flexible and able to adapt to rapidly changing environments. Further, as a source of experimentation and innovation, microenterprises play an integral role in the renewal processes, specifically, Schumpeter's $(1942,1961)$ innovation, which often changes the market structure (Robbins et al., 2000). This "churning" is at the theoretical heart of the advocates' arguments as to why microbusinesses are vital to state and national welfare (Headd, 1997).

Some argue that because microenterprises tend to be more labor intensive they are better able to promote employment growth. Others suggest that because most microenterprises are drawing from secondary labor markets (e.g., lower education levels, women, minorities, immigrants, etc.) the promotion of small business may represent a poverty mitigation strategy (Partridge and Rickman, 2006). Binks and Jennings (1986) stress the insulation against the deleterious effects of recession as one of the primary benefits of promoting small businesses. Because microenterprises are operating at peak efficiency, are more dependent on their small workforce, and build stronger ties between workers and management within the firm, they are less likely to lay off employees. Quintana and Pulignano (2006) maintain that because many small businesses are family owned and operated there is not only greater opportunity for employees to have face-to-face discussions with their employers, but also the sense of "family" within the business creates powerful forces to minimize lay offs.

Small- and medium-sized businesses have also become an integral part of cluster development as advanced by Porter (1990, 1996, 1998a, 1998b, 2000). As noted by Woodward and Guimarães (2009) and Goetz, Deller, and Harris (2009), Porter's clusters have become the focal point of many state and local economic development efforts. Some, such as Maskell and Kebir (2006), have argued that Porter and his advocacy of clusters has almost single-handedly spurred interest in rethinking economic development theory and policies. One important outgrowth of this new thinking is the concerted movement away from the "shoot anything that

\footnotetext{
${ }^{1}$ There are some exceptions which use micro-level data to examine regional growth trends such as Craig and Kohlhase (2006) which used firm level data to explore growth patterns in Houston, TX. Relevant to this research they (p. 1) conclude: "We thus interpret this evidence to strongly suggest that small firms are a crucial element in urban economic development as their success is likely to lead to economic growth not only for the firm itself, but for the entire local economy."
}

(C) Southern Regional Science Association 2011. 
flies, claiming anything that lands" (Rubin, 1988) mentality toward more strategic behavior in identifying the specific types of industry that should be promoted at the local and regional levels.

Germane to this research is the fundamental role that small businesses play in clusters and cluster development (Pitelis and Pseirdis, 2006). Within the rapidly growing cluster literature there is growing recognition and evidence that a cluster of small firms can be more innovative than large firms (Montana and Nenide, 2008). Indeed, Sacchetti and Tomlinson (2006) note that within the spirit of Porter's notion of clusters, economic development policy makers and practitioners favor placing a greater emphasis upon small-firm development and encouraging greater networking between firms within and across localities, thus reducing the risks of 'strategic failure'. In a study of Japanese manufacturing, Ozawa (2000) argues that the Fordism approach of extreme vertical integration was rejected in favor of a network, or cluster, of small and medium sized enterprises (SME) which contracted with a larger central manufacturer. Examples would include Toyota's decision to locate most of its suppliers within a one hour drive time as well as Fiat's operations in Italy.

There are an equal number of powerful arguments that maintain that small businesses and microenterprises, in particular, are not the engine of economic growth that small business advocates claim. Central to these arguments is endogenous growth theory, which provides the context for arguing in favor of larger firms. Specifically, the powers of economies of scale and scope and the ability to finance research and development and bring to market the fruits of that research embodies Schumpeter's notion of innovation. Small businesses and microenterprises do not have the resources to make noticeable impacts on the economy. Second, research has suggested that outside of developed economies where institutions (e.g., property rights, contract law, etc.) are well established the role of microbusinesses is unclear. In other words, in developing countries the cards may be stacked against small businesses breaking through. Third, the available macro-empirical research is unclear as to causation; simple correlations between microenterprises and growth are not sufficient to base policy on.

As Shaffer (2006) suggests, most studies looking at the relationship between small businesses and growth tend to be micro-oriented and industry specific, and hence may not be appropriate to draw policy implications concerning macroeconomic or regional growth. But as noted by Shaffer, Deller, and Marcoullier (2006) as well as Deller and Goetz (2009), the "Third Wave" of development strategies focuses on collaboration and partnership building within and across economies. The focus on cluster development today has its roots in agglomeration economies and the ideas flowing from endogenous growth theory where both internal and external economies matter (Thisse and Fujita, 2002). A cluster of small businesses can not only capture Schumpeter's innovative entrepreneur but also capture endogenous growth through agglomeration economies as embodied in clusters. Further, in a micro-level study of high-tech industries in Sweden, Wennberg, and Lindqvist (2010) found that entrepreneurs located within a cluster have survival rates that are better than those of similar firms outside the cluster. More recently, Henderson and Weiler (2010) found that entrepreneurial activity has a stronger impact on several measures of economic growth in more densely urban areas. Indeed, Braunerhjelm et al. (2010) find that small businesses are vital to the diffusion of knowledge within endogenous growth theory. Clearly, spatial patterns matter.

One central area of confusion within this literature is the overlap between small business development and entrepreneurship. While Schumpeter's notion of innovation and entrepreneurship as a driving characteristic of economic growth and development is widely 
agreed upon, how we measure entrepreneurship for empirical analysis is a source of frustration. One challenge is that not all small firms are necessarily entrepreneurial, and not all entrepreneurial firms are small. As noted by Goetz, et al. (forthcoming) there is also the so-called 'reactive' and 'radical' entrepreneurship which adds yet another layer of complication. Specifically, 'reactive' forms of entrepreneurship occur when individuals feel compelled to start a business because of a recent economic crisis (e.g., a plant closing) or a persistent local economic downturn. Alternative employment opportunities are exhausted and the individual is not mobile for any number of reasons ranging from the inability to sell a home in a depressed market to psychic costs of leaving the community. As a last resort the individual starts a business. This pattern stands in stark contrast to the dynamic, creative forms of 'radical' or Schumpeterian entrepreneurship and small business creation that policymakers want to foster.

Equally important is the role of what Julien (2007) refers to as "mundane" entrepreneurship. As a community or region grows market threshold theory (see Shaffer, Deller, and Marcouiller, 2004) predicts that market opportunities for small businesses open. At certain thresholds certain types of businesses, such as a small grocery store, hardware store or tavern, become economically viable. In studies of small business development some researchers (e.g., Gorton, 1999; Keeble, Walker, and Robson, 1993) have argued that most small businesses fall into Julien's notion of the mundane entrepreneur, which is fundamentally different from Schumpeter's innovative or 'radical' entrepreneur who is essential to endogenous growth theory. When one thinks about the differences between the entrepreneur who sees a market opportunity for a coffee shop and a university researcher who starts a small business to bring a new innovation to market it becomes clear that not all small businesses have the same affect on economic growth.

Even so, areas with a greater intensity of small businesses are likely to be more entrepreneurial, to the extent that such business owners are working for themselves rather than seeking out or waiting for an employer to offer them paid positions. Furthermore, the relative returns to self-employment in a county may provide clues about the success and productivity of entrepreneurs. In addition, the decision to start or even buy an existing small business reveals certain elements of entrepreneurial spirit. From a practical policy perspective, the question remains if local economic development policy makers and practitioners should devote limited resources to the promotion of small businesses or focus on larger businesses. This research attempts to address a simple question: Is a heavy concentration of small microenterprises associated with higher rates of economic growth. The distinction between Schumpeterian, reactionary or mundane is beyond the scope of this study.

A more practical problem with this literature is the definition of a small business or microenterprise. Acs (1999, p8) speaks of the "standard definition of a small firm employing fewer than 500 employs" while Beck, Demirgüç-Kunt, and Levine (2003) as well as Aquilina, Klump, and Pietrobelli (2006) use a threshold of 250 employees; Robbins et al. (2000) use a threshold of 20 employees for one set of analysis and 500 for another; Craig and Kohlhase (2006) use a threshold of 45 employees. Some researchers such as Shaffer $(2002,2006)$ use average firm size to draw inferences. Unfortunately, theory provides little insight into what amounts to a question of definition. In a sense, whether small businesses have a role in influencing economic growth, coupled with a viable working definition of what constitutes a small business, is an empirical question. Loveridge and Nizalov (2007) specifically examine the distribution of firm size in a study of Michigan and find that the optimal growth-enhancing 
distribution of employment has a higher share of the smallest businesses (with one to four employees) than the average. They conclude that the results support policies emphasizing small business start-ups and development.

For this research I focus attention on microenterprises as firms that have between one and four employees for four reasons. First, based on the work of Loveridge and Nizalov (2007), local economies that have a predominance of these microenterprises tend to be associated with stronger economic growth. Second, according to U.S. County Business Patterns, of the approximately 7.4 million enterprises that have an Employer Identification Number used by the Internal Revenue Service (IRS) for employee payroll taxes, 54.4 percent have between one and four employees. ${ }^{2}$ If I used the larger definition of small businesses, specifically firms with less than 250 employees, 99.3 percent of all businesses would be considered small. Third, if businesses this small do influence economic growth, than the results lend stronger credence to the position of microenterprise advocates then similar results obtained using the larger business definition. Finally, as argued by Muske and Woods (2004), many local economic development practitioners advocate spending their limited resources working with small firms within their service areas. The rationale centers on the idea that within most communities the predominance of firms are very small, tend to be started and owned by local people and hence are less likely to relocate, and are in the most need of the services offered by economic development practitioners. As advocated by Shaffer, Deller and Marcouiller (2006) many of these services can range from simple one-on-one business counseling to providing simple market analysis to providing forums for business networking. By focusing on the smallest of microenterprises this research hopes to provide insights into the viability of economic development practitioners focusing on small businesses.

In this research I am particularly interested in spatial variation in the relationship between microenterprises and economic growth. This interest is based on three questions or issues. First, if clustering does play a role in helping understand the relationship between small business development and economic growth there, spatial nature of those clusters should matter. If one simply maps location quotients for the U.S. counties by increasingly finer levels of industrial detail, the spatial clusters become more readily apparent. For example, randomly selecting the location quotient for mining input supply firms and mapping it shows a clear spatial pattern (Figure 1). If spatial clustering matters, it follows that the relationship between small firms, or in the case of this study, microenterprises, should follow distinct spatial patterns.

Second, as described below, classical statistical analysis along with traditional spatial econometric methods provide a global parameter estimate and do not easily allow for spatial heterogeneity in the relationship between microenterprises and economic growth. While one could allow for some spatial variation by using spatial expansion methods (Cassetti, 1972), which allow parameters of the variables of interest to vary over space by interacting them with local information, these methods easily become cumbersome and unyielding. The simplest example would be to use regional slope shifters within a dummy variable framework and then to look for patterns in the slope shifters. ${ }^{3}$

\footnotetext{
${ }^{2}$ This does not include sole proprietorships without employees. If I included sole proprietorships without employees in our definition, like the Association for Enterprise Opportunity (AEO) does, then microbusinesses would account for over 80 percent of all businesses in the U.S. Another problem with sole proprietorship is that many of these businesses are in effect inactive.

${ }^{3}$ Clearly, the spatial expansion method is not the only approach that has been offered to address spatial heterogeneity. As noted by Ertur, Le Gallo, and LeSage (2007) in the Review within the growth convergence literature there is growing acknowledgement
} 


\section{FIGURE 1. Employment Location Quotients for Mining Input Supply Industries}

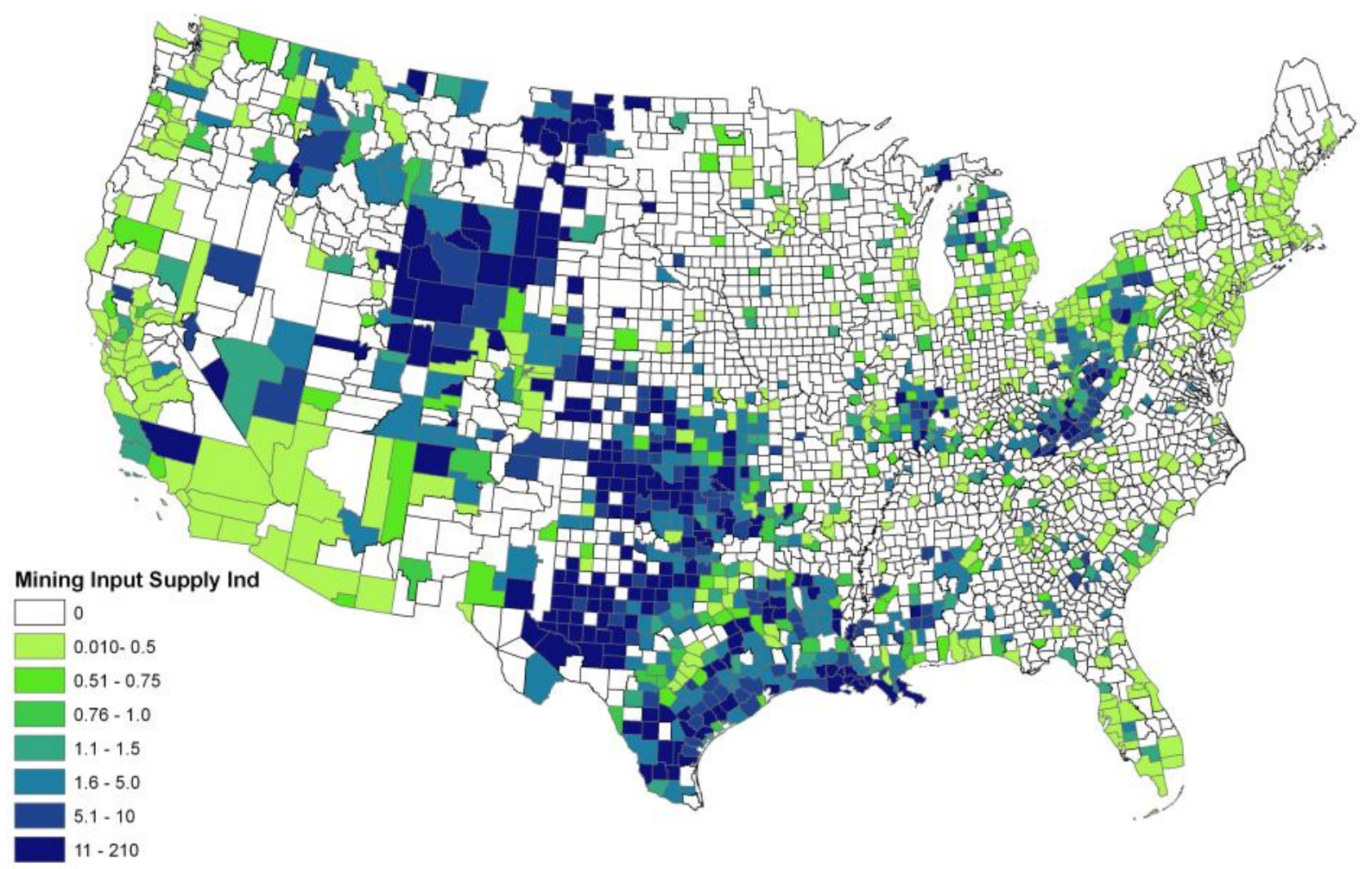

An alternative would be to employ Geographically Weighted Regression (GWR) as developed by developed by Fotheringham and his colleagues in a series of papers (Brunsdon, Fotheringham, and Charlton, 1996, 1998, 1999a, 1999b; Fotheringham, Charlton, and Brunsdon, 1997a, 1997b, 1998; Fotheringham, Brunsdon, and Chartlon, 2002). As described in more detail below, GWR is specifically designed to efficiently allow and test for spatial heterogeneity in parameter estimates. Indeed, in a study of the local Tucson, Arizona housing markets Bitter, Mulligan and Dall'erba (2007) find that GWR outperforms spatial expansion methods in terms of the ability to explain the data and predictive precision. Thus for this study I use GWR to allow and test for spatial heterogeneity in the relationship between microenterprises and regional economic growth.

My third reason for allowing and testing for spatial variation in the relationship between microenterprises and economic growth hinges on policy recommendations. If spatial dependency matters and the role of small businesses varies over space, then greater insights into policy recommendations can be gained. Specifically, if no spatial heterogeneity is found then the policy implications are more uniform over the U.S. On the other hand, if there is spatial heterogeneity, what may work in the Mountainous West may not also apply to the Appalachia regions of the U.S. In addition, as with most research, if spatial heterogeneity is found it raises more refined questions as to why. While clustering theory tells us that spatial heterogeneity is present and that the role of microenterprises should vary over space, it does not inform us why.

that regions may be converging to heterogeneous equilibrium which traditional OLS methods will mask with a simple global convergence parameter. Thus, several approaches have been offered, such as a locally linear Bayesian spatial model suggested by Ertur, Le Gallo, and LeSage (2007) or the spatial autoregressive local estimator (SALE) offered by Pace and LeSage (2004).

(C) Southern Regional Science Association 2011. 
The research proceeds by employing a Carlino-Mills (1987) model of economic growth to provide structure to the models. In the following section, I briefly outline the theoretical growth framework and empirical specifications. Data are for U.S. counties for the period 1990 to 2000. I selected this time period to make use of the NORSIS data set of natural resource amenities developed by the U.S. Forest Service. The selection of control variables is based on the results of previous work using Bayesian Modeling Averaging (BMA) methods (Deller and Lledo, 2007; Deller, Lledo, and Marcouiller, 2008). These latter studies also employ the 1990 to 2000 period. Given these prior BMA results, microenterprise metrics are introduced into the model and I use Geographically Weighted Regression (GWR) to look for spatial heterogeneity in the role of microenterprises in economic growth. The bulk of the data is drawn from the 1990 and 2000 Census along with the BEA-REIS and County Business Patterns.

\section{MODEL OF ECONOMIC GROWTH}

Models of regional economic growth often focus on the interdependencies of house residential and firm location choices. Often this view addresses the notion of whether "people follow jobs" or "jobs follow people" (Steinnes and Fisher, 1974). To address this issue of causation and interdependency, Carlino and Mills (1987) constructed a now classic two equation system. This model has subsequently been used by a number of regional scientists to examine regional economic growth (see Boarnet, Chalermpong, and Geho, 2005 for a detailed review).

The general form of the model is:

$$
\begin{aligned}
& P^{*}=f\left(E^{*} \mid \Omega^{P}\right) \\
& E^{*}=g\left(P^{*} \mid \Omega^{E}\right)
\end{aligned}
$$

where $P^{*}$ and $E^{*}$ are equilibrium levels of population and employment and $\Omega^{P}$ and $\Omega^{E}$ are a set of variables describing initial conditions and other historical information. Contained in the latter set of information are measures of microenterprises.

Relying on the equilibrium conditions laid out above, a simple linear representation of those conditions can be expressed as:

$$
\begin{aligned}
& P^{*}=\alpha_{\mathrm{op}}+\beta_{1 p} E^{*}+\Sigma \delta_{\mathrm{I} p} \Omega^{P} \\
& E^{*}=\alpha_{\mathrm{o} E}+\beta_{1 E} P^{*}+\Sigma \delta_{\mathrm{I} E} \Omega^{E}
\end{aligned}
$$

Moreover, population and employment likely adjust to their equilibrium levels with substantial lags (i.e., initial conditions). Partial adjustment equations to the equilibrium levels are:

$$
\begin{aligned}
& P_{t}=P_{t-1}+\lambda_{P}\left(P^{*}-P_{t-1}\right) \\
& \mathrm{E}_{\mathrm{t}}=\mathrm{E}_{\mathrm{t}-1}+\lambda_{\mathrm{E}}\left(\mathrm{E}^{*}-\mathrm{E}_{\mathrm{t}-1}\right)
\end{aligned}
$$

After slight rearrangement of terms this yields:

$$
\begin{aligned}
& \Delta P=P_{t}-P_{t-1}=\lambda_{P}\left(P^{*}-P_{t-1}\right) \\
& \Delta E=E_{t}-E_{t-1}=\lambda_{E}\left(E^{*}-E_{t-1}\right)
\end{aligned}
$$

where $\lambda_{P}$ and $\lambda_{E}$ are speed of adjustment coefficients to the desired levels of population, employment and income, respectively, which are generally positive; $\Delta P$ and $\Delta E$ are the region's changes in population and employment respectively; $P_{t-1}$ and $\mathrm{E}_{t-1}$ are initial conditions of 
population and employment. Substituting and rearranging terms allows us to express the linear representation of the model that is to be estimated as:

$$
\begin{gathered}
\Delta P=\alpha_{\mathrm{op}}+\beta_{1 p} P_{t-1}+\beta_{2 \mathrm{p}} \mathrm{E}_{\mathrm{t}-1}+\gamma_{1 p} \Delta E+\Sigma \delta_{\mathrm{Ip}} \Omega^{P}{ }_{t-1} \\
\Delta E=\alpha_{\mathrm{oE}}+\beta_{1 E} P_{t-1}+\beta_{2 E} E_{t-1}+\gamma_{1 \mathrm{p}} \Delta \mathrm{P}+\Sigma \delta_{\mathrm{IE}} \Omega^{E}{ }_{t-1}
\end{gathered}
$$

Note that the speed of adjustment coefficient $(\lambda)$ becomes embedded in the linear coefficient parameters $\alpha, \beta, \gamma$, and $\delta$. This framework is particularly useful for this analysis because it allows us to capture structural relationships while simultaneously isolating the influence of microbusiness attributes on regional economic growth. In essence, we are modeling short-term adjustments (i.e., $\Delta P$ and $\Delta E$ ) to long-term equilibrium (i.e., $P^{*}$ and $E^{*}$ ).

One of the advantages of using this partial adjustment framework is that issues of endogeneity are sidestepped (Hunt, 2006). In practice the set of control variables $\Omega^{P}$ and $\Omega^{E}$ are lagged in such a way that we have variables in time $t-1$ regressed on to changes over $t-1$ to $t$. But Boarnet, Chalermpong, and Geho (2005) acknowledge that the presence of lagged starting values of the dependent variables can create a cause for concern. If there are "deep lags" embedded into the dynamics of the regional economy then endogeneity can become an issue. But as observed by Putnam (2000, p.137) in his discussion of social capital, the arrows of causation, or issues related to endogeneity, are "as tangled as well-tossed spaghetti." In the end, one could argue that deep lags are always present in regional economies and that all of the control variables contained in $\Omega^{P}$ and $\Omega^{E}$ are influenced by not only population and employment levels but also levels and rates of change.

The regional economic growth literature is subject to the same critique to which the larger macroeconomic growth literature has been subject - that is, the specification of the "conditional variables," as they are commonly termed: in the present paper they are more precisely $\Omega^{P}$ and $\Omega^{E}$. As argued by Levine and Renelt (1992), Pack (1994), Sala-I-Martin (1997), Schultz (1999), Durlauf and Quah (1999), Brock and Durlauf (2000), and Islam (2003), the growth literature is awash with studies that document the correlation of a host of variables with growth, and there is little if any theoretical foundation for the selection of control variables. The lack of any theoretical insights, or in the case of conflicting theoretical predictions, the determinants of growth reduce to an empirical question. To a large extent the commonly followed approach is to throw everything we have against the wall and see what sticks.

One method that has been suggested by Brock and Durlauf (2000) and expanded upon by Brock, Durlauf, and West (2007) and employed in modeling the growth of U.S. counties by Deller and Lledo (2007) and Deller, Lledo, and Marcouiller (2008) is that of a Bayesian Modeling Average approach. Bayesian Model Averaging (BMA) is a method to deal with the problem of making reliable inferences about a given theoretical hypothesis, which can be based on a number of alternative statistical models presenting similar explanatory power. The problem is that that theory tells us that there should be a range of potential control variables embedded in $\Omega^{\mathrm{P}}$ and $\Omega^{\mathrm{E}}$ from institutional factors to human capital to economic structure to amenities and the nebulous notion of quality of life. The Bayesian solution to this problem starts by assuming that each regression parameter is drawn from a distribution function conditional on the model as well as on the dataset used. Based on this prior assumption, it then proceeds to estimate the posterior probability of occurrence of each model given the dataset. A final estimate of the regression

(C) Southern Regional Science Association 2011. 
parameter is made by averaging its expected value over the set of all possible models weighted by each model's posterior probability of occurrence.

For this research I rely on the results of Deller and Lledo (2007) and Deller, Lledo, and Marcouiller (2008) to determine the set of control variables $\Omega^{P}$ and $\Omega^{E}$. Deller and Lledo (2007), for example, hypothesize that there are ten broad classifications of factors influencing regional economic growth: historical growth patterns (i.e., deep lags), market demands (i.e., regional demand characteristics), market supply (i.e., regional supply, specifically labor characteristics), credit markets, infrastructure, government, economic structure, agglomerations, geographical location, and politics. Within many of the classifications there are subsets of characteristics. For example, the market supply, or labor classification, includes labor force participation rates and education measures along with health and crime measures. Using the Bayesian Modeling Averaging 57 potential control variables were reduced to 15. In essence the results of Deller and Lledo (2007) and Deller, Lledo, and Marcouiller (2008) inform the relevant set of control variables that are included in $\Omega^{P}$ and $\Omega^{E}$. Once this set is determined, then specific variables of interest, such as metrics of small and/or micro businesses, can be systematically introduced and examined.

For this study I follow Deller and McConnon (2009) and Atasoy, McConnon, and Gabe (2006) and define and measure microenterprises as the percent of all businesses that have between one and four employees. In addition, I follow the suggestions of Shaffer (2002) and disaggregate microenterprises into four sectors based on the one-digit SIC level. By disaggregating I hope to provide insights into whether or not industry type matters in helping to explain the role of microenterprises in economic growth. Since clustering theory tells us that spatial variation exists in the relationship between small business development and economic growth, the aggregation of microenterprises into one large industrial group is likely to mask clustering effects. Indeed, one could rightly argue that using one-digit SIC aggregations does not allow a sufficient level of industry specificity to draw any meaningful policy implications. The data used for this study are the same as those used in Deller and Lledo (2007) and Deller, Lledo, and Marcouiller (2008) with the addition of microenterprise firm data which is drawn from the County Business Patterns and is reflective of 1990.

\section{SPATIAL ESTIMATION METHODS}

As noted in the introductory comments, Geographically Weighted Regression (GWR), as developed by Fotheringham and his colleagues (Brunsdon, Fotheringham, and Charlton, 1996, 1998, 1999a, 1999b; Fotheringham, Charlton, and Brunsdon, 1997a, 1997b, 1998; Fotheringham, Brunsdon, and Chartlon, 2002), is becoming a widely popular spatial modeling technique in regional science. For example Partridge et al. (2008) use GWR to study U.S. rural employment patterns, Partridge and Rickman (2007) also study U.S. rural poverty patterns, Nakaya (2001) uses GWR to explore Japanese migration patterns, Jensen and Deller (2007) use GWR in a study of elder migration patterns in the U.S. Gordon Mulligan and his colleagues have used GWR to examine crime patterns (Cahill and Mulligan, 2007) and housing prices (Bitter, Mulligan, and Dall'erba, 2007) in Tucson, Arizona. Over time GWR has become a valuable method for examining spatial heterogeneity in the parameter space.

In addition, GWR has received much attention in the spatial econometrics literature. The basic approach has been expanded upon by Páez, Uchida, and Miyamoto (2002a, 2002b) by introducing maximum likelihood estimation of the kernel bandwidths (eq.14 below) and spatial 
autocorrelation among the residuals, attempts to address multicollinearity by Wheeler and Tiefelsdorf (2005), as well as the introduction of Bayesian GWR by LeSage (2004) and methods to incorporate flow data between spatial observations (Nakaya, 2001).

By using the methods of GWR as outlined in detail by Fotheringham, Brunsdon, and Chartlon (2002), one can extend previous models of spatial inquiry by allowing the explanatory variables to have differential effects across geographical space; this is compared to the more traditional assumption that the variable has the same influence over all locations. By allowing for the parameters to spatially vary I can explicitly test to see if the role of microenterprises in economic growth varies over space. For example, does a higher concentration of manufacturing firms with between 1-4 employees affect population and employment growth differently in the Great Plains than in southern California, New England, or the Mississippi Delta? By allowing for such spatial variation, more focused policy recommendations can be offered.

In the context of this research a GWR model will be used to investigate spatial variation in the factors that influence U.S. regional economic growth. The GWR model can be written as:

$$
\mathbf{y}(h)=\beta(h) \mathbf{x}+\varepsilon,
$$

where $(h)$ indicates that parameter estimates are to occur at a location whose coordinates are given by the vector $(g)$. Where the parameters in OLS are estimated with:

$$
\beta=\left(\mathbf{X}^{\prime} \mathbf{X}\right)^{-1} \mathbf{X}^{\prime} \mathbf{Y},
$$

the parameters are estimated in GWR using a weighting scheme:

$$
\beta(h)=\left[\mathbf{X}^{\prime} \mathrm{W}(h) \mathbf{X}\right]^{-1} \mathbf{X}^{\prime} \mathrm{W}(h) \mathbf{Y} .
$$

The weights are chosen such that those points nearer to the point of estimation are weighted more heavily than those further away. The function for the weighting scheme is Gaussian, with the $i^{\text {th }}$ observation being defined as:

$$
w_{i}(h)=\exp \left(-\frac{d}{b}\right)^{2},
$$

where $d$ is the distance between observation $i$ and location $g$, and where $b$ is the bandwidth estimated using cross-validation. The spatial weighting schemes in GWR can be made to adapt themselves to the size variations in the density of the data; larger bandwidths in sparser areas and smaller bandwidths in more highly concentrated areas. This will be used to highlight the degree of misspecification on the global model.

To test to see if the spatial variations in the parameter estimates are statistically significant Fotheringham, Brunsdon, and Chartlon (2002) suggest the use of Monte Carlo significance tests first suggested by Hope (1968). In this version of the GWR software (Fotheringham, Brunsdon, and Chartlon, 2002) the number of local model simulations is set to 100. After the observed variance of the local parameter estimate is calculated and stored, 99 sets of variances are obtained for each variable based on different randomizations of the observed data. The $p$-value is then computed for the local parameters for each variable in the model. These $p$-values indicate whether the spatial variation is significant or if it most likely occurred by chance.

(C) Southern Regional Science Association 2011. 


\section{EMPIRICAL RESULTS}

Two sets of analysis are presented and discussed. The first is the global relationship between microenterprises and economic growth using classical ordinary least squares regression (Table 1) and the second is the presence of spatial variation in those relationships using Geographically Weighted Regression (Tables 2 and 3). Each set of results are considered in turn. The population growth equation performs well explaining 62.7 percent of the variation in growth, and as expected the results are consistent with Deller and Lledo (2007) and Deller, Lledo, and Marcouiller (2008). For example, higher historical growth patterns in population, employment and income growth are associated with higher levels of population growth. ${ }^{4}$ A higher share of the population that is non-white as well as the percent of the population over 65 years of age is associated with slower population growth. All government factors filtered through the Bayesian Modeling Average are associated with lower levels of population growth. This suggests that U.S. counties that are more dependent on the public sector for employment or have higher local tax burdens will experience slower population growth. More urban areas, as measured by population density, will have higher population growth rates, which is consistent with endogenous growth theory. The employment growth model has lower explanatory power with an adjusted $R^{2}$ of 0.2615 but also performs as expected based on Deller and Lledo (2007) and Deller, Lledo, and Marcouiller (2008). But based on the BMA results, historical growth in per capita income, the poverty rate and percent of the population living on farms are not included in the employment growth equation. But generally, the control variables that are in both the population and employment growth equations tend to complement each other; factors that dampen population growth are also associated with slower employment growth.

The results for how microenterprises influence growth in population and employment are particularly interesting. First, the percent of firms that are classified as microenterprises appear to have no influence on population growth but a positive and statistically significant impact on employment growth. A similar result is revealed for the percent of retail establishments that have between one and four employees. Third, the percent of microenterprises in finance, insurance and real estate (F.I.R.E.) have a statistically significant positive impact on both population and employment growth. Finally, the share of service firms that are microenterprises has a positive impact on population growth but no statistically significant influence on employment growth.

These results allow for two conclusions concerning the influence of microenterprises on economic growth. First, there is no evidence that a higher share of firms that are classified as microenterprises tends to have a dampening impact on growth. Second, variation in statistical significance levels across the two measures of growth and the types of industry suggest that a weaker version of the assertion that small businesses and microenterprises in particular have a positive role in economic growth is supported. Rather, their role and influence "depend" on the metric of economic growth and the specific industry type considered. This conclusion is consistent with Deller and McConnon (2009) and their analysis of the U.S. states. But as with any study of regional economic growth, care must be taken in drawing too strong of a conclusion from these results. While the theory tells us that small businesses are an important part of the regional economic growth puzzle, it would be in error to suggest that a larger share of local

\footnotetext{
${ }^{4}$ The fact that the data support the notion of "deep lags" in the growth process reinforces the concern over endogeneity within models of regional economic growth. Unfortunately, as noted by Boarnet, Chalermpong, and Geho (2005), it is neither clear that an appropriate instrument exists nor what the best approach might be for addressing this problem.
} 
TABLE 1: Classical Regression Growth Models 1990-2000

\begin{tabular}{|c|c|c|}
\hline Variables & Population & Employment \\
\hline Intercept & $\begin{array}{r}-28.8615 \\
(0.00)\end{array}$ & $\begin{array}{r}-9.2804 \\
(0.13)\end{array}$ \\
\hline Lagged Growth in Per Capita Income: 1979-1989 & $\begin{array}{r}0.0574 \\
(4.44)\end{array}$ & N.A. \\
\hline Lagged Growth in Population: 1979-1989 & $\begin{array}{r}0.5292 \\
(0.00)\end{array}$ & $\begin{array}{r}0.5636 \\
(0.00)\end{array}$ \\
\hline Lagged Growth in Employment: 1979-1989 & $\begin{array}{r}0.0572 \\
(0.00)\end{array}$ & $\begin{array}{r}0.0323 \\
(0.28)\end{array}$ \\
\hline Percent of the Population Non-white & $\begin{array}{r}-0.0639 \\
(0.00)\end{array}$ & $\begin{array}{r}-0.0459 \\
(0.18)\end{array}$ \\
\hline Percent of the Population over Age 65 & $\begin{array}{r}-0.3602 \\
(0.00)\end{array}$ & $\begin{array}{r}-0.6648 \\
(0.00)\end{array}$ \\
\hline Median Number of Vehicles per Household & $\begin{array}{r}19.2116 \\
(0.00)\end{array}$ & $\begin{array}{r}9.4199 \\
(0.00)\end{array}$ \\
\hline Percent of Population with a Bachelor's Degree & $\begin{array}{r}0.0727 \\
(0.08)\end{array}$ & $\begin{array}{r}0.7182 \\
(0.00)\end{array}$ \\
\hline Poverty Rate & $\begin{array}{r}0.2175 \\
(0.00)\end{array}$ & N.A. \\
\hline Percent of the Population Living on Farms & $\begin{array}{r}-0.3224 \\
(0.00)\end{array}$ & N.A. \\
\hline Percent of the Population Foreign Born & $\begin{array}{r}-0.1296 \\
(0.05)\end{array}$ & $\begin{array}{r}-0.6826 \\
(0.00)\end{array}$ \\
\hline Per Capita Local Taxes & $\begin{array}{r}-0.0045 \\
(0.00)\end{array}$ & $\begin{array}{r}-0.0080 \\
(0.00)\end{array}$ \\
\hline State and Local Gov't Employment per 10,000 Population & $\begin{array}{r}-0.0044 \\
(0.00)\end{array}$ & $\begin{array}{r}-0.0074 \\
(0.00)\end{array}$ \\
\hline Federal Gov't Civilian Employment per 10,000 Population & $\begin{array}{r}-0.0019 \\
(0.08)\end{array}$ & $\begin{array}{r}-0.0101 \\
(0.00)\end{array}$ \\
\hline Military Employment per 10,000 Population & $\begin{array}{r}-0.0002 \\
(0.00)\end{array}$ & $\begin{array}{r}-0.0004 \\
(0.00)\end{array}$ \\
\hline Population Density & $\begin{array}{r}0.5714 \\
(0.00)\end{array}$ & $\begin{array}{r}0.0511 \\
(0.88)\end{array}$ \\
\hline Percent of Manufacturing Firms Classified as Microenterprise & $\begin{array}{r}0.2278 \\
(0.84)\end{array}$ & $\begin{array}{r}7.9057 \\
(0.00)\end{array}$ \\
\hline Percent of Retail Firms Classified as Microenterprise & $\begin{array}{r}1.8385 \\
(0.44)\end{array}$ & $\begin{array}{r}22.7755 \\
(0.00)\end{array}$ \\
\hline Percent of F.I.R.E. Firms Classified as Microenterprise & $\begin{array}{r}5.0924 \\
(0.00)\end{array}$ & $\begin{array}{r}12.0317 \\
(0.00)\end{array}$ \\
\hline Percent of Service Firms Classified as Microenterprise & $\begin{array}{r}6.6606 \\
(0.00)\end{array}$ & $\begin{array}{r}0.9536 \\
(0.86)\end{array}$ \\
\hline Adjusted $R^{2}$ & 0.6267 & 0.2615 \\
\hline
\end{tabular}


businesses that are small or micro causes population and/or employment growth. From these results the best inference we can make is that the data are consistent expectations: a higher share of certain types of businesses that are small tend to be positively associated with higher levels of population and employment growth.

Turning attention to the GWR results provides additional insights into the role microenterprises play in economic growth. A simple likelihood ratio test, based on the $F$ test, can be used to compare the abilities of the GWR and global (OLS) models to replicate the observed data. In other words, the simple $F$ statistic tests the null hypothesis that the GWR model represents no improvement of the global (OLS) model. For the population growth model presented in Table 2, the $F$ statistic is 7.7406 and for the employment growth model presented in Table 3, the $F$ statistic is 5.5977. Given degrees of freedom of 20 and 124 for the population model and 17 and 114 for the employment model, the critical value of the $F$ statistic at the 95 percent level of confidence is about 1.65. I can reasonably conclude that the GWR result for both models is preferred to the OLS results.

Before turning to the specific results outlined in Tables 2 and 3, consider the overall performance of the population and employment models. One way to do this is to consider the local $R^{2}$ which provides a measure of how well the model is performing across each spatial observation. For the population model the average local $R^{2}$ is .7080 with a range of 0.4855 to 0.7492 and a standard deviation of 0.0513 (Figure 2). The model performs the strongest, as

\section{FIGURE 2. Population Model Local $\boldsymbol{R}^{2}$}

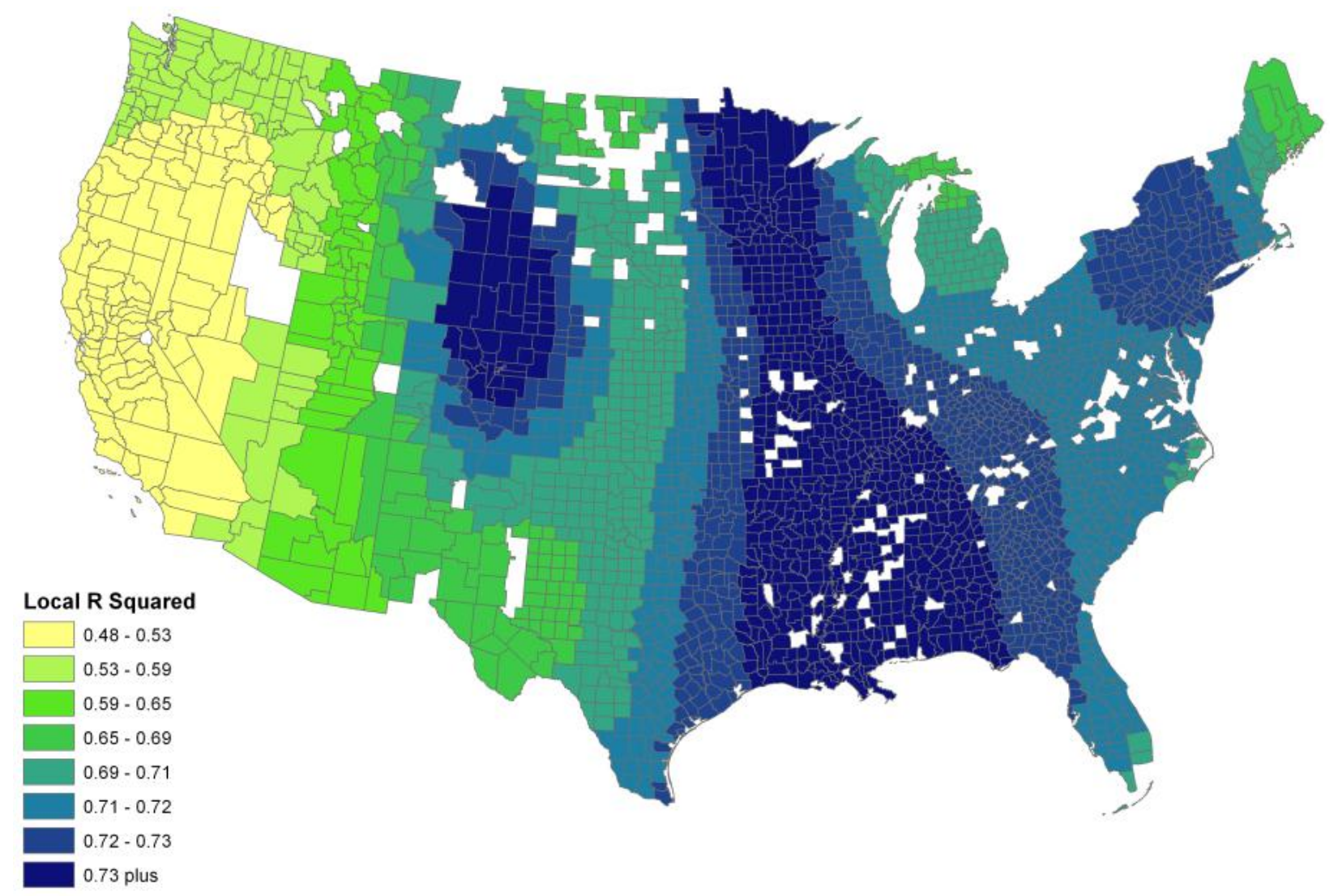

(C) Southern Regional Science Association 2011. 


\section{FIGURE 3. Employment Model Local $\boldsymbol{R}^{2}$}

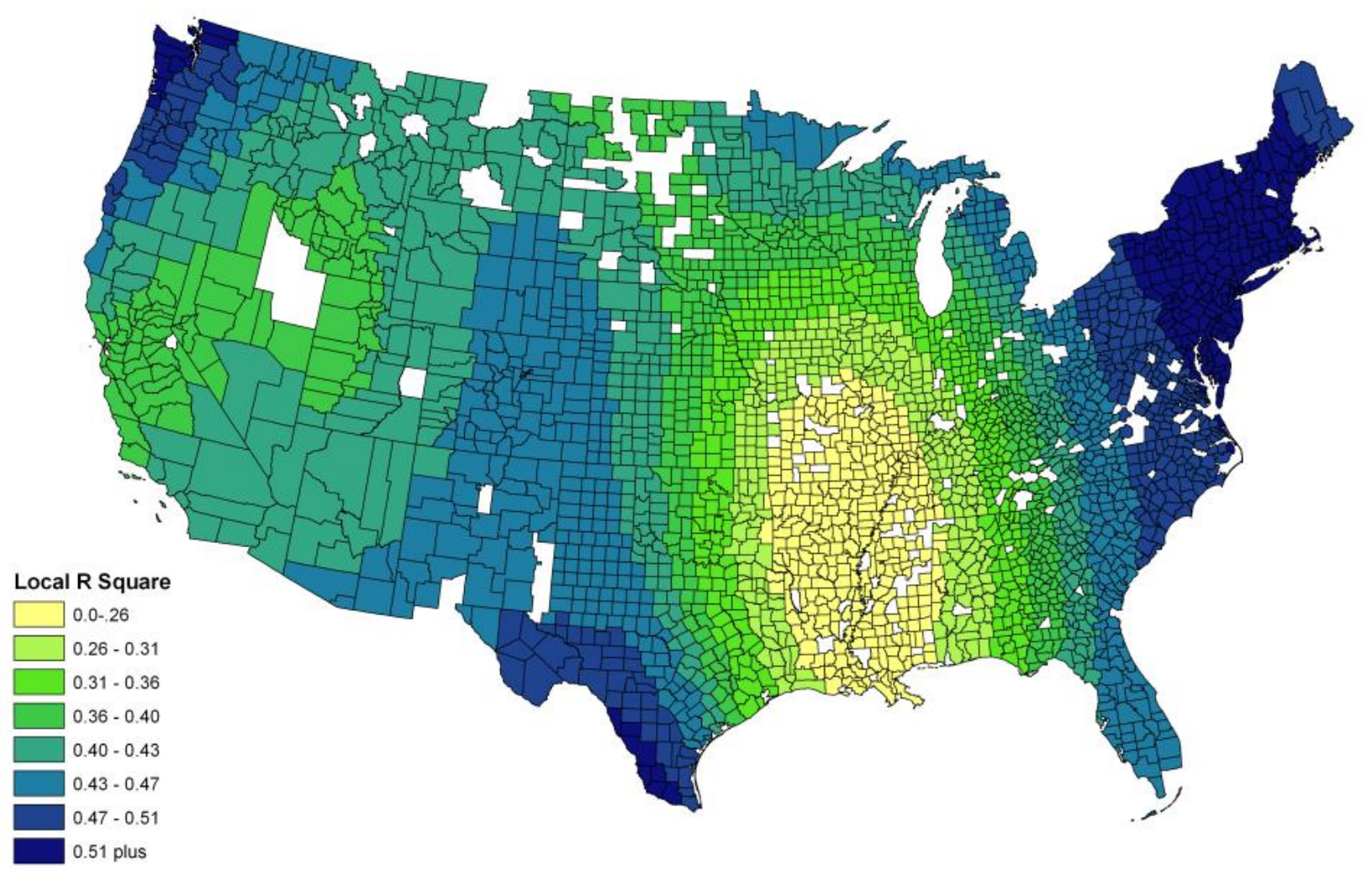

measured by the $R^{2}$, along the Mississippi River in the heart of the U.S. along with the region around Denver in the Mountainous West. While still explaining about 50 percent of the variation in population growth, the model performed the poorest along the West Coast. The employment model does not perform as strongly as the population model with an average local $R^{2} 0.3880$ with a range of 0.2088 to 0.5463 and a standard deviation of 0.0844 (Figure 3). Unlike the population model, the employment model had the lowest explanatory power in the Mississippi River area, particularly the St. Louis area and south. The employment model has the most explanatory power in the Pennsylvania to New England region, the southern parts of Texas and the Seattle region.

The relatively higher average local $R^{2}$ for both the population and employment models generated by Geographically Weighted Regression compared to the overall $R^{2}$ from the traditional least squares estimator lends additional support to the idea that the GWR is preferred over least squares. But the variation in the local $R^{2}$ over the U.S. counties tells us that the models do a better job of explaining economic growth in some parts of the country than in others. This result should not be surprising in that we know that the Mississippi Delta, for example, is different from New England, which in turn is different from the Great Plains. The GWR approach allows us to begin to better document those differences. This spatial variation also has direct policy implications; global policies implemented at the national level will have different impacts across the U.S. Although this latter result has been widely accepted within the economic development literature (e.g., Shaffer, 2001; Honadle, 2001), the results presented here start to provide insights into how those spatial differences might play out. 
TABLE 2. GWR Population Growth Model

\begin{tabular}{|c|c|c|c|c|c|c|}
\hline Variable & Minimum & $\begin{array}{c}\text { Lower } \\
\text { Quartile }\end{array}$ & Median & $\begin{array}{c}\text { Upper } \\
\text { Quartile }\end{array}$ & Maximum & $\begin{array}{l}\text { Monte } \\
\text { Carlo } \rho\end{array}$ \\
\hline Intercept & -92.8510 & -34.8167 & -26.5585 & -13.7260 & 68.2312 & 0.00 \\
\hline Lagged Growth in Per Capita Income: 1979-1989 & -0.0841 & 0.0507 & 0.0809 & 0.1312 & 0.2015 & 0.00 \\
\hline Lagged Growth in Population: 1979-1989 & 0.1974 & 0.5376 & 0.5845 & 0.6350 & 0.6840 & 0.18 \\
\hline Lagged Growth in Employment: 1979-1989 & 0.0136 & 0.0332 & 0.0560 & 0.0900 & 0.1909 & 0.88 \\
\hline Percent of the Population Non-white & -0.7742 & -0.1149 & -0.0594 & -0.0259 & 0.1674 & 0.00 \\
\hline Percent of the Population over Age 65 & -0.6528 & -0.4126 & -0.2676 & -0.1647 & 0.2881 & 0.03 \\
\hline Median Number of Vehicles per Household & -11.0421 & 11.4879 & 17.1088 & 20.0016 & 43.3151 & 0.00 \\
\hline Percent of Population with a Bachelor's Degree & -0.2900 & -0.0904 & -0.0409 & 0.1221 & 0.7221 & 0.00 \\
\hline Poverty Rate & -0.4202 & 0.1374 & 0.2184 & 0.2632 & 0.8440 & 0.00 \\
\hline Percent of the Population Living on Farms & -1.0801 & -0.2164 & -0.1323 & -0.0810 & 0.7263 & 0.00 \\
\hline Percent of the Population Foreign Born & -1.1763 & -0.4910 & -0.1963 & 0.0238 & 0.8227 & 0.00 \\
\hline Per Capita Local Taxes & -0.0081 & -0.0031 & -0.0018 & 0.0002 & 0.0047 & 0.03 \\
\hline State and Local Gov’t Employment per 10,000 Population & -0.0145 & -0.0071 & -0.0043 & -0.0018 & 0.0004 & 0.00 \\
\hline Federal Gov't Civilian Employment per 10,000 Population & -0.0143 & -0.0031 & -0.0016 & 0.0001 & 0.0045 & 0.29 \\
\hline Military Employment per 10,000 Population & -0.0008 & -0.0004 & -0.0004 & -0.0002 & 0.0000 & 0.68 \\
\hline Population Density & -2.7040 & 0.2036 & 0.5977 & 1.0232 & 3.2113 & 0.23 \\
\hline Percent of Manufacturing Firms Classified as Microenterprise & -7.9142 & -1.5205 & -0.3657 & 0.6744 & 22.6041 & 0.15 \\
\hline Percent of Retail Firms Classified as Microenterprise & -41.3946 & -8.4716 & -3.4213 & 3.3109 & 24.2110 & 0.03 \\
\hline Percent of F.I.R.E. Firms Classified as Microenterprise & -57.8023 & 3.8748 & 5.1274 & 6.2886 & 9.8068 & 0.00 \\
\hline Percent of Service Firms Classified as Microenterprise & -32.8035 & 4.2317 & 9.3918 & 13.7905 & 21.3264 & 0.02 \\
\hline
\end{tabular}

(C) Southern Regional Science Association 2011. 
TABLE 3. GWR Employment Growth Model

\begin{tabular}{|c|c|c|c|c|c|c|}
\hline Variable & Minimum & $\begin{array}{c}\text { Lower } \\
\text { Quartile }\end{array}$ & Median & $\begin{array}{c}\text { Upper } \\
\text { Quartile }\end{array}$ & Maximum & $\begin{array}{l}\text { Monte } \\
\text { Carlo } \rho\end{array}$ \\
\hline Intercept & -65.8035 & -10.2377 & -2.3548 & 9.2580 & 131.8522 & 0.00 \\
\hline Lagged Growth in Per Capita Income: 1979-1989 & 0.1906 & 0.4523 & 0.5547 & 0.7031 & 1.2336 & 0.08 \\
\hline Lagged Growth in Population: 1979-1989 & -0.1883 & 0.0630 & 0.0902 & 0.1243 & 0.3244 & 0.55 \\
\hline Lagged Growth in Employment: 1979-1989 & -0.9224 & -0.0576 & 0.0000 & 0.0735 & 0.2445 & 0.10 \\
\hline Percent of the Population Non-white & -1.4780 & -0.7415 & -0.5162 & -0.2933 & 0.7936 & 0.19 \\
\hline Percent of the Population over Age 65 & -35.9628 & 1.6947 & 7.6051 & 11.6609 & 44.4997 & 0.00 \\
\hline Median Number of Vehicles per Household & 0.0002 & 0.4815 & 0.6055 & 0.8115 & 2.1902 & 0.18 \\
\hline Percent of Population with a Bachelor's Degree & -2.3208 & -1.3283 & -0.8567 & -0.4613 & 0.6342 & 0.02 \\
\hline Poverty Rate & -0.0140 & -0.0085 & -0.0046 & -0.0019 & 0.0032 & 0.13 \\
\hline Percent of the Population Living on Farms & -0.0256 & -0.0108 & -0.0079 & -0.0054 & 0.0047 & 0.11 \\
\hline Percent of the Population Foreign Born & -0.0263 & -0.0118 & -0.0088 & -0.0065 & -0.0019 & 0.94 \\
\hline Per Capita Local Taxes & -0.0021 & -0.0009 & -0.0006 & -0.0004 & 0.0000 & 0.24 \\
\hline State and Local Gov't Employment per 10,000 Population & -9.6647 & -2.8973 & -1.1399 & 0.6741 & 2.9223 & 0.11 \\
\hline Federal Gov’t Civilian Employment per 10,000Population & -8.6797 & 0.0301 & 2.1474 & 3.9509 & 32.3976 & 0.91 \\
\hline Military Employment per 10,000 Population & -57.3957 & -3.9547 & 2.4232 & 18.3985 & 122.7976 & 0.46 \\
\hline Population Density & -59.0496 & 6.8847 & 12.0565 & 14.8078 & 20.6891 & 0.04 \\
\hline Percent of Manufacturing Firms Classified as Microenterprise & -37.7369 & -3.0867 & 5.7943 & 12.6237 & 28.0810 & 0.77 \\
\hline Percent of Retail Firms Classified as Microenterprise & -65.8035 & -10.2377 & -2.3548 & 9.2580 & 131.8522 & 0.00 \\
\hline Percent of F.I.R.E. Firms Classified as Microenterprise & 0.1906 & 0.4523 & 0.5547 & 0.7031 & 1.2336 & 0.08 \\
\hline Percent of Service Firms Classified as Microenterprise & -0.1883 & 0.0630 & 0.0902 & 0.1243 & 0.3244 & 0.55 \\
\hline
\end{tabular}

(C) Southern Regional Science Association 2011. 
Two sets of results are presented in Tables 2 and 3. First, the GWR estimated coefficients are quartiled, with minimum, lower quartile, median, upper quartile and maximum values being reported. Second, Hope's (1968) Monte Carlo significance test procedure along and its marginal significance values are reported. For the population growth model, 14 of 20 coefficients exhibit significant spatial variation, but for the employment growth model only 4 of 17 coefficients exhibit statistically significant spatial variation. These results taken at face value tell us that care must be taken when drawing local or regional policy conclusions based on global parameter estimates, particularly with respect to population growth.

Because of the volume of results I will limit my discussion here to just the role of microenterprises in population and employment growth. For population growth three of the four types of microenterprises exhibit significant spatial variation and only for manufacturing does the global parameter estimate appear to be stable over space. Consider first microenterprise retail firms. From the global OLS results there appears to be a positive but statistically insignificant result. But from the GWR estimator there appears to be significant spatial variation ranging from a minimum of -41.3946 to a maximum of 24.2110 and a median value of -3.4213 . By mapping the individual coefficients a clearer picture of the relationship between microenterprise retail firms and population growth becomes apparent (Figure 4). ${ }^{5}$ Here we can clearly see that a higher share of retail firms with between one and four employees is associated with negative population growth along the Pacific Coast and the East Central U.S. ranging from

FIGURE 4. Spatial Heterogeneity of Retail within the Population Model

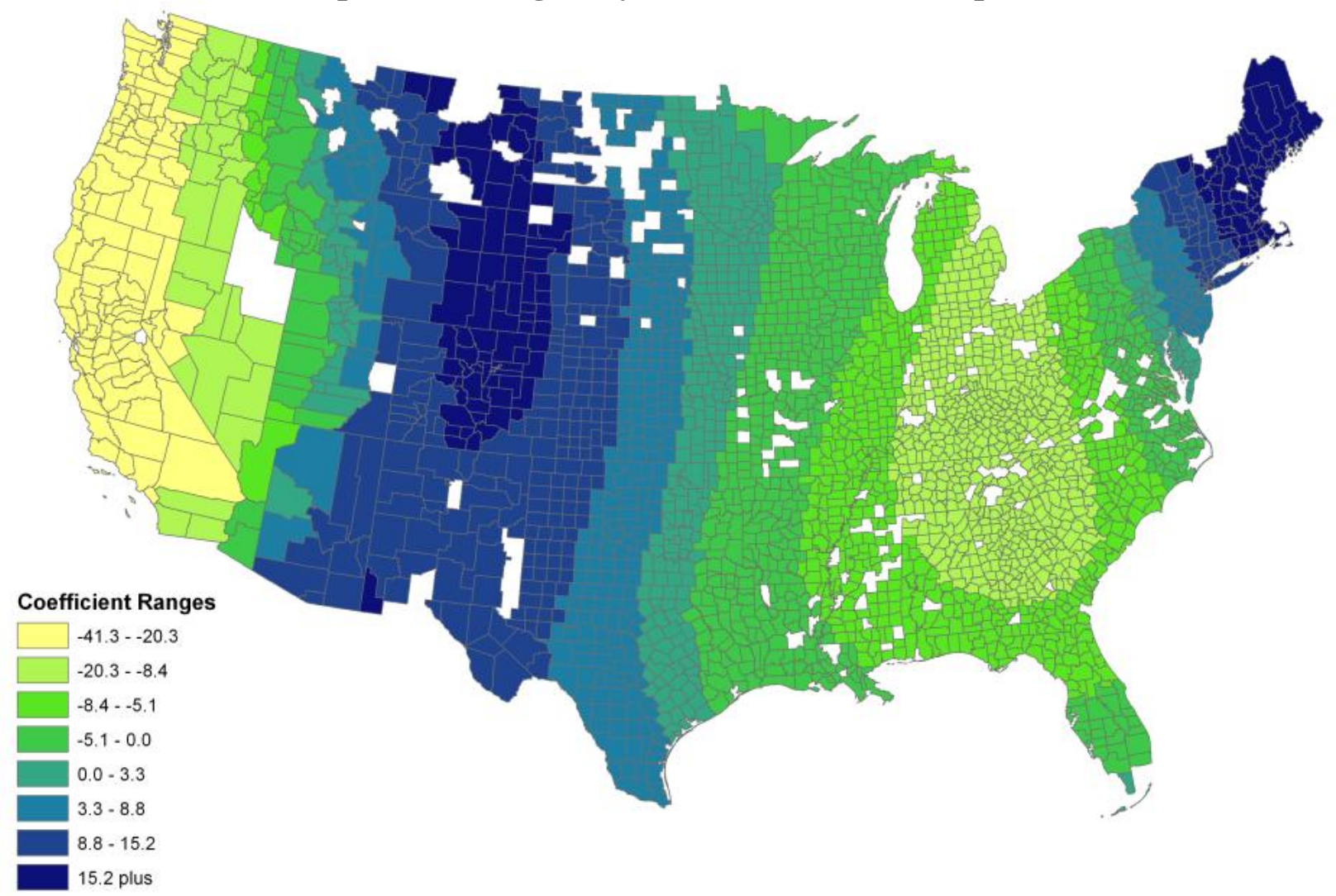

${ }^{5}$ Please note that missing data appear as white areas on the maps. 
Michigan to the upper portions of Florida, but has a positive influence from the southern tip of Texas to Montana as well as in New England.

Now consider the role of microenterprise service firms in population growth (Figure 5). From the OLS results there appears to be a positive and statistically significant relationship, suggesting that a higher share of service firms that have between one and four employees will have a positive influence on population growth. But the GWR results, which are statistically significant, suggest that the coefficients range from a low of -32.8035 to a high of 21.3263 with a median of 9.3918. The median value coincides with the OLS derived global value but the observed range of negative values again suggests that the role very small service firms play in U.S. population growth is more complex than what can be provided with a simple global parameter. Mapping the GWR coefficients tells us that there tends to be a negative relationship between small service firms and population growth in the western U.S., particularly the Coastal Pacific and parts of New England, but a positive relationship from New York to Florida to Texas to Minnesota. It is also of interest to note a swath from northern Arizona to parts of Colorado where the positive relationship between micro service firms and population growth becomes stronger.

The spatial pattern continues with a positive and significant global OLS coefficient for very small finance, insurance and real estate (F.I.R.E.) which supports the position of small firm advocates; but the GWR results vary from a minimum of -57.8023 to a maximum of 9.8086 with a median of 5.1274, which is reasonably close to the global coefficient of 5.0924. Mapping the

\section{FIGURE 5. Spatial Heterogeneity of Services within the Population Model}

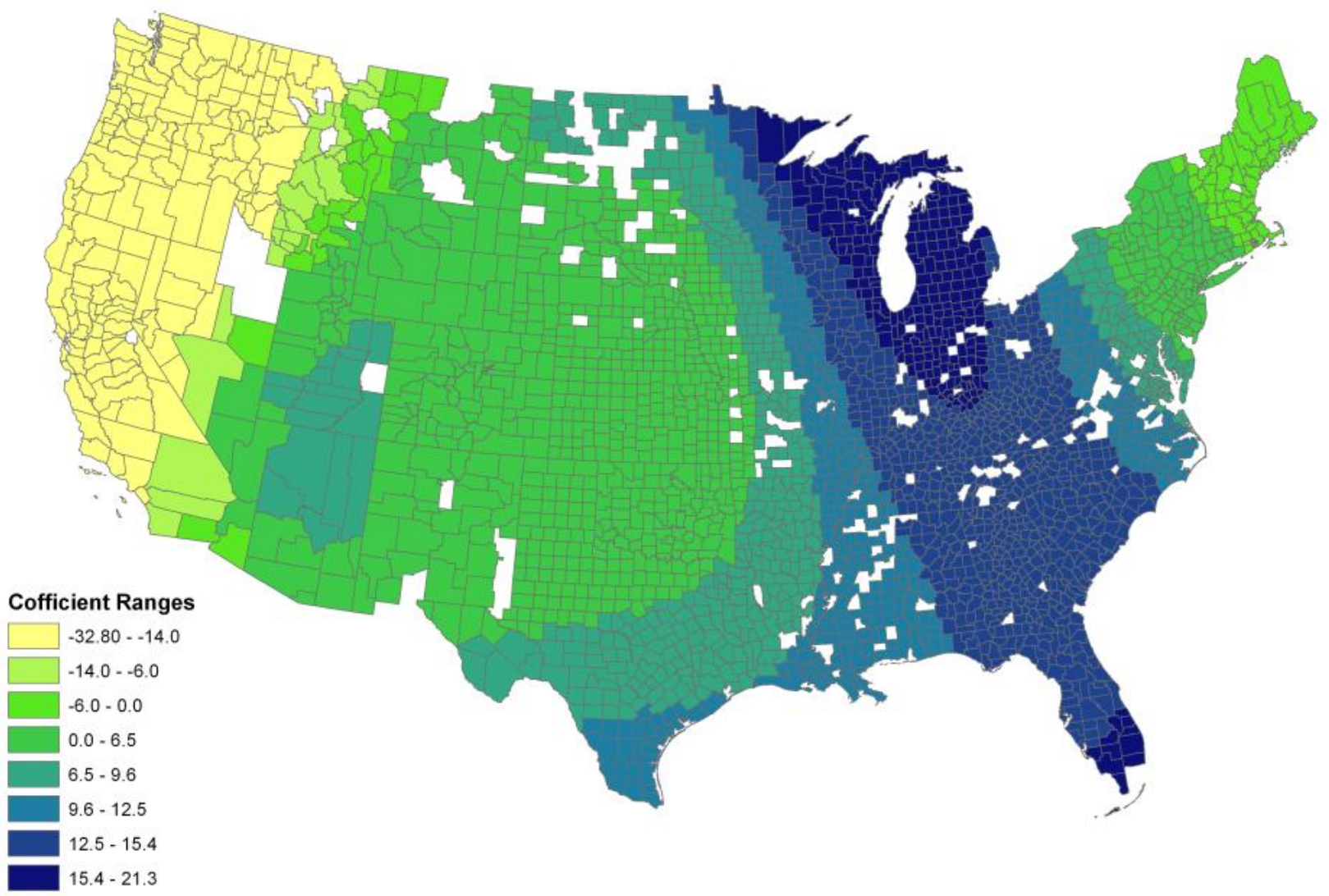

(C) Southern Regional Science Association 2011. 
GWR results (Figure 6) again reveals that the negative coefficients tend to be in the western U.S. and California in particular and northern New England, but positive throughout much of the rest of the U.S. with the largest positive values ranging from New York to Florida to Wisconsin (Figure 3). There is also a pocket of large positive coefficients in Idaho and western Montana.

A couple of patterns begin to emerge from the discussion of the population growth model. First, it is clear that policies promoting the development of very small businesses will have a very different impact on population growth across the U.S. Policies aimed at promoting very small services, finance, insurance and real estate firms may have a positive impact on population growth in the eastern U.S. but may actually have negative impacts on the far western counties. At the same time the promotion of small retail firms may have detrimental effects in much of the eastern U.S. and the far west, but a positive impact in the swath of the U.S. from New Mexico and Arizona north to Montana. Unfortunately, the results do not provide any insights into patterns that are uncovered. Theory states that spatial differences should exist and evidence of those differences are revealed, but why these specific patterns are revealed is unclear.

Turning attention to the employment growth model, the GWR results suggest that there is much less spatial variation in the values of the model coefficients. As mentioned above, only three variables, other than the intercept term, exhibit statistically significant spatial variation. One of the three, however, is the share of finance, insurance and real estate (F.I.R.E.) firms that

FIGURE 6. Spatial Heterogeneity of F.I.R.E. within the Population Model

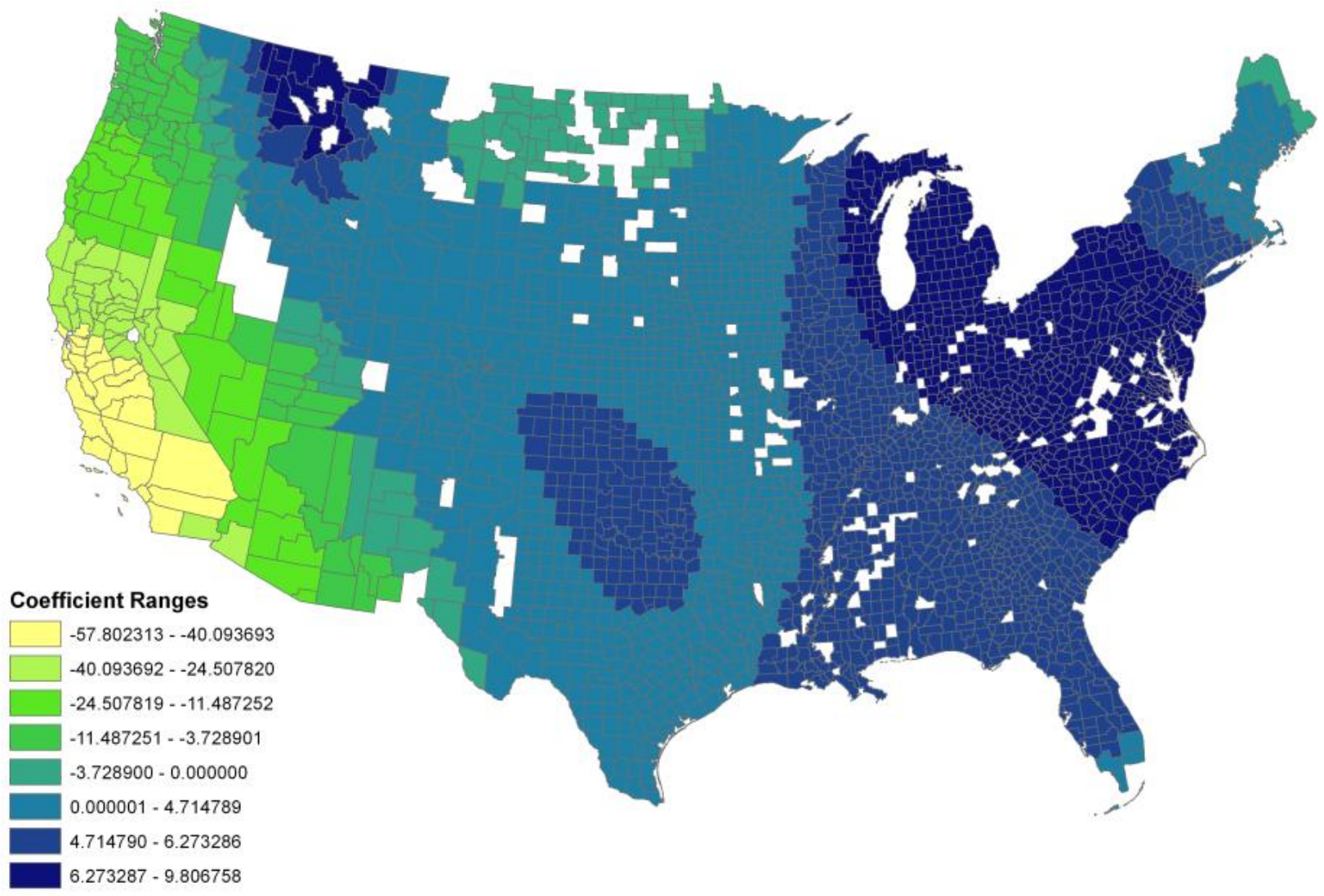

(C) Southern Regional Science Association 2011. 
have between one and four employees. The global OLS coefficient is 12.0317 as is very close to the median GWR coefficient which is 12.0565 but the GWR coefficients range from a minimum of -59.0496 to a maximum of 20.6891. Mapping the GWR coefficients (Figure 7) reveals what is now becoming a familiar pattern. The western U.S. ranging from southern Texas to Seattle tends to exhibit a negative relationship between very small F.I.R.E. firms; the negative relationship is particularly large in California. There is also a small part of northern Maine that exhibits a negative relationship. For the rest of the nation, as well as a pocket in Colorado, there is a positive relationship between the share of F.I.R.E. firms that are classified as microenterprises and employment growth. But recalling the relatively low local $R^{2}$ s should give some pause in drawing too strong of a conclusion. The strength of the employment model in the Mid-Atlantic states coupled with the relatively large positive coefficients on F.I.R.E. from much of Illinois east to the western part of New England suggests that policies aimed at promoting small businesses in this sector may have a vastly different impact in the north-easterly part of the U.S. than in the west.

The results of this applied research study have three general conclusions. First, microenterprises do play a role in better understanding population and employment growth. Second, that role varies by type of industry and metric of growth. Third, there is significant spatial variation in those roles. The policy implications are clear: the promotion of microenterprises as an economic development strategy is a viable option but care must be taken to consider local conditions. What may work in the middle of the U.S. may not work on the West Coast.

\section{FIGURE 7. Spatial Heterogeneity of F.I.R.E. within the Employment Model}

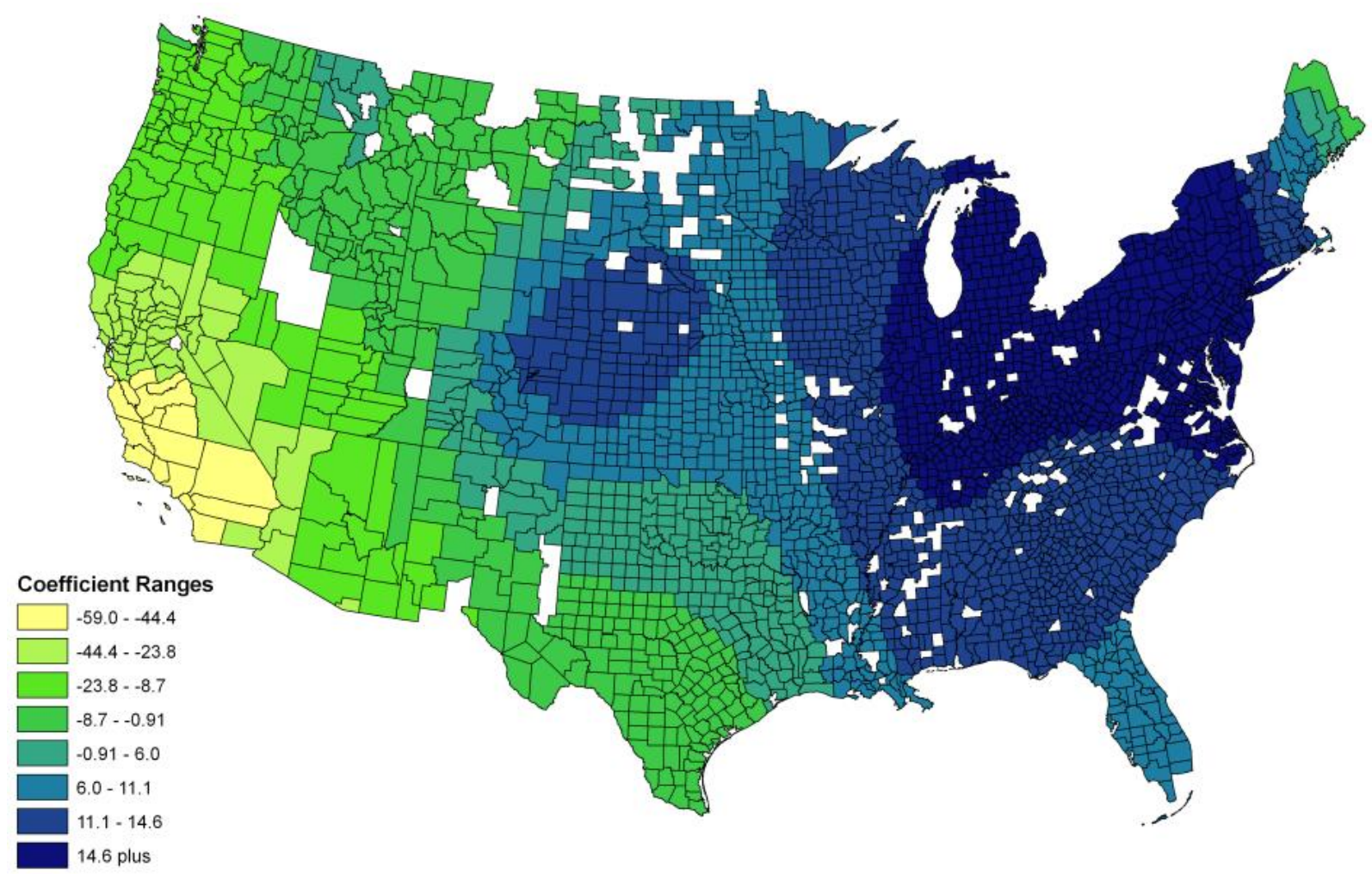

(C) Southern Regional Science Association 2011. 


\section{CONCLUSIONS}

The role of small business in economic growth has been a hot topic of debate since the work of Birch (1979). Competing theories tell us that small businesses are more efficient and innovative - particularly within a cluster setting - and thus lead to higher levels of economic growth. Other theories, in particular endogenous growth theory, tell us that economies of scale and scope exhibited by large firms allow for higher levels of research and development and the introduction of innovation which in turn generates economic growth. Competing theories that pull policy in opposite directions, means that the ultimate policy choice must be empirically decided: that is, it boils down to an issue of which theory the data support.

In this study I have tried to provide a unique empirical approach to exploring the role of microenterprises in economic growth. I use the Carlino-Mills model of regional economic growth and the Bayesian Modeling Average results of Deller and Lledo (2007) and Deller, Lledo, and Marcouiller (2008) to select a set of control variables. I also use Geographically Weighted Regression (GWR) to examine spatial variation in the relationship between the control variables and my measures of small businesses and regional economic growth. Data are for U.S. counties and examine growth over the 1990s.

The empirical results are encouraging and three general conclusions can be drawn. First, small firms with between one and four employees do play a role in better understanding regional economic growth. Second, that role varies by type of industry and metric of growth. Third, there is significant spatial variation in those roles. The spatial results suggest that a higher share of total number of firms that are classified as microenterprises have a positive role in explaining population and employment growth in the eastern and middle parts of the U.S. but tends to have a dampening affect in the Coastal Pacific regions of the U.S. This spatial variation is particularly evident in population growth but is less evident in employment growth.

The policy implications of this work are clear. First, the empirical results generally support the position of small business advocates. Other than the Coastal Pacific region the promotion of very small businesses as an economic development strategy is a viable option. The results also suggest that care must be taken to account for local conditions: what may work in one part of the U.S. may not work in another. Still, the results provide support for policies that are targeted toward the promotion of small businesses.

Future work on modelling small business development and economic growth must not only be sensitive to spatial variations, but also refine the industry classifications used in this study. For example, aggregating all manufacturing into one large group looses significant heterogeneity within manufacturing. The same observation can be applied to the service sector. Examining population and employment growth offers a very narrow view of economic growth and development. Other metrics of economic performance such as poverty and income levels must also be considered. Are these results sensitive to the definition of microenterprises used in this study? Would altering the definition to be between one and ten employees or less than 20 employees alter the results and policy implications? The final limitation to the approach taken in this study is that the vitally important role of entrepreneurship is masked over. In short, entrepreneurial innovation is key to economic growth and microenterprise is not synonymous with entrepreneurship. This study has provided valuable insights into the small business and economic growth question but additional work is required. 


\section{REFERENCES}

Acs, Zoltan J. (1999) Are Small Firms Important: Their Role and Impact. Kluwer Academic Publishers: Boston, MA.

Acs, Zoltan J. and David B. Audretsch. (1993) Small Firms and Entrepreneurship. Kluwer Academic Publishers: Boston, MA.

(1990). The Economics of Small Firms: A European Challenge. Kluwer Academic Publishers: Boston, MA.

Aquilina, Matteo, Rainer Klump, and Carlo Pietrobelli. (2006). "Factor Substitution, Average Firm Size and Economic Growth," Small Business Economics, 26, 203-214.

Atasoy, Sibel, James C. McConnon Jr., and Todd Gabe. (2006) "The Economic Importance and Impact of Microenterprises to the New England Economy," Resource Economics and Policy Department Staff Paper No. 560, University of Maine.

Beck, Thorten, Asli Demirgüç-Kun, and Ross Levine. (2003) "Small and Medium enterprises, Growth and Poverty: Cross-Country Evidence," World Bank Policy Research Working Paper 3178, December.

Binks, Martin R. and A. Jennings. (1986) "Small Firms as a Source of Economic Rejuvenation," in James Curran, John Stanworth, and David Watkins (eds.), The Survival of the Small Firm: The Economics of Survival and Entrepreneurship. Gower: Aldershot, U.K., pp. 19-38.

Birch, David L. (1979) The Job Generation Process: Final Report to Economic Development Administration. MIT Program on Neighborhood and Regional Change: Cambridge, MA.

(1987) Job Creation in America: How Our Smallest Companies Put the Most People to Work. Free Press: New York.

Bitter, Chris, Gordon F. Mulligan, and Sandy Dall'erba. (2007) "Incorporating Spatial Variation in Housing Attribute Prices: A Comparison of Geographically Weighted Regression and the Spatial Expansion Method," Journal of Geographical Systems, 9, 7-27.

Blair, John P. (1999) "Local Economic Development and National Growth," Economic Development Review, 16, 93-97.

Boarnet, Marlon G., Saksith Chalermpong, and Eilizabeth Geho. (2005) "Specification Issues in Models of Population and Employment Growth," Papers in Regional Science, 84, 21-46.

Bradshaw, Terry K. and Edward J. Blakely. (1999) "What Are "Third-Wave" State Economic Development Efforts? From Incentives to Industrial Policy," Economic Development Quarterly, 13, 229-244.

Braunerhjelm, Pontus, Zoltan J. Acs, David B. Audretsch, and Bo Carlsson. (2010) "The Missing Link: Knowledge Diffusion and Entrepreneurship in Endogenous Growth," Small Business Economics, 34, 105-125

Brock, William and Steven Durlauf. (2000) "Growth Economics and Reality," The World Bank Economic Review, 15, 229-272.

(C) Southern Regional Science Association 2011. 
Brock, William, Steven Durlauf, and Kenneth D. West. (2007) "Model Uncertainty and Policy Evaluation: Some Theory and Empirics," Journal of Econometrics, 136, 629-664.

Brown, Charles, James Medoff, and Jay Hamilton. (1990) Employers: Large and Small. Harvard University Press: Cambridge, MA.

Brunsdon Chris, A. Stewart Fotheringham, and Martin Charlton. (1996) "Geographically Weighted Regression: A Method for Exploring Spatial Non-stationarity," Geographical Analysis, 28, 281-298.

. (1998) "Geographically Weighted Regression: Modelling Spatial Non-stationarity," Statistician, 47, 431-443.

. (1999a) "Some Notes on Parametric Significance Tests for Geographically Weighted Regression,” Journal of Regional Science, 39, 497-524.

. (1999b) "A Comparison of Random Coefficient Modelling and Geographically Weighted Regression for Spatially Non-stationary Regression Problems," Geographical and Environmental Modelling, 3, 47-62.

Cahill, Meagan and Gordon F. Mulligan. (2007) "Using Geographically Weighted Regression to Explore Local Crime Patterns,” Social Science Computer Review, 25, 174-193.

Carlino, Gerald A. and Edwin S. Mills. (1987) “The Determinants of County Growth,” Journal of Regional Science, 27, 39-54.

Cassetti, Emilio. (1972). "Generating Models by the Expansion Method: Applications to Geographical Research," Geographical Analysis, 4, 81-92.

Craig, Steven G. and Janet E. Kohlhase. (2006) "The Economic Role of Small Businesses Using Large Data Sets: An Analysis of the Contribution of Small Firms to Urban Growth." Report to the US Department of Commerce Small Business Administration under contract SBAHQ-04-Q-0023. Available in March 2011 at http://www.sba.gov/advo/research/rs287tot.pdf.

Davis, Steven J., John Haltiwanger and Scott Schuh. (1994) "Small Business and Job Creation: Dissecting the Myth and Reassessing the Facts," In Lewis Solmon and Alec R. Levenson (eds.), Labor Markets, Employment and Job Creation. Westview Press: Boulder, CO, pp. 297-315.

. (1996) Job Creation and Destruction. MIT Press: Cambridge, MA.

Deller, Steven C. and Stephan J. Goetz. (2009) "Historical Description of Economic Development Policy," In Stephan J. Goetz, Steven C. Deller, and Thomas Harris (eds.), Targeting Regional Economic Development. Routledge: London, pp. 17-34.

Deller, Steven C. and Victor Lledo. (2007). "Amenities and Rural Appalachian Growth," Agricultural and Resource Economics Review, 36, 107-132.

Deller, Steven C. and James C. McConnon, Jr. (2009) "Microenterprises and Economic Growth: A Panel Study of the US States 1977 to 1997," Applied Economic Letters, 16, 13071312.

Deller, Steven C., Victor Lledo, and David W. Marcouiller. (2008) "Modeling Regional Economic Growth with a Focus on Amenities," Review of Urban \& Regional 
Development Studies, 20, 1-21

Dunne, Timothy, Mark J. Roberts, and Larry Samuelson. (1989) "Growth and Failure of U.S. Manufacturing Plants," Quarterly Journal of Economics, 104, 671-698.

Eisinger, Peter. (1988) The Role of the Entrepreneurial State. University of Wisconsin Press: Madison, WI.

(1995) "State Economic Development in the 1990s: Politics and Policy Learning," Economic Development Quarterly, 9, 146-158.

Ertur, Cem, Julie Le Gallo, and James P. LeSage. (2007) "Local versus Global Convergence in Europe: A Bayesian Spatial Econometric Approach," Review of Regional Studies, 37, 82108.

Fotheringham, A. Stewart, Martin Charlton, and Chris Brunsdon. (1997a) "Measuring Spatial Variations in Relationships with Geographically Weighted Regression," In Michael M. Fischer and Arthur Getis (eds.), Recent Developments in Spatial Analysis. Springer: New York, pp. 60-82.

. (1997b) "Two Techniques for Exploring Non-Stationarity in Geographical Data," Geographical System, 4, 59-82

(1998) "Geographically Weighted Regression: A Natural Evolution of the Expansion Method for Spatial Data Analysis," Environment and Planning A, 30, 1905-1927

Fotheringham, A. Stewart, Chris Brunsdon, and Martin Charlton. (2002) Geographically Weighted Regression: The Analysis of Spatially Varying Relationships. Wiley: Chichester.

Goetz, Stephan J., Steven C. Deller, and Thomas Harris. (2009) "Targeted Regional Economic Development: Introduction and Overview," In Stephan J. Goetz, Steven C. Deller, and Thomas Harris (eds.), Targeting Regional Economic Development. Routledge; London, pp. 1-14.

Goetz, Stephan J., Mark Partridge, Steven C. Deller, and David Flemming. (2010) "Evaluating Rural Entrepreneurship Policy in the U.S.," Journal of Regional Analysis and Policy, 40, 20-33.

Gorton, Matthew. (1999) "Spatial Variations in Markets Served by UK-Based Small and Medium-Sized Enterprises (SMEs)," Entrepreneurship and Regional Development, 11, $39-55$.

Haltiwanger, John and C. J. Krizan. (1999) "Small Business and Job Creation in the United States: The Role of New and Young Businesses," In Zoltan J. Acs (ed.), Are Small Firms Important? Kluwer Academic Publishers: Boston, pp. 52-79.

Headd, Brian. (1997) Small Business Growth by Major Industry, 1988-1995. U.S. Small Business Administration, Office of Advocacy: Washington, DC. Available in February 2011 at http://archive.sba.gov/advo/stats/ind88_95.pdf.

Henderson, Jason and Stephen Weiler. (2010) "Entrepreneurs and Job Growth: Probing the Boundaries of Time and Space," Economic Development Quarterly, 24, 23-32.

(C) Southern Regional Science Association 2011. 
Honadle, Beth W. (2001) "Rural Development Policy in the United States: Beyond the Cargo Cult Mentality," Journal of Regional Analysis and Policy, 23, 93-108.

Hope, Adery C. A. (1968) "A Simplified Monte Carlo Significance Test Procedure," Journal of the Royal Statistical Society Series B, 30, 582-598.

Hunt, Gary. (2006) "Population-Employment Models: Stationarity, Cointegration, and Dynamic Adjustments," Journal of Regional Science, 46, 205-244.

Islam, Nazrul. (2003) "What Have We Learned from the Convergence Debate?," Journal of Economic Surveys, 17, 309-362.

Jensen, Tomas and Steven C. Deller. (2007) "Spatial Modeling of the Migration of Older Persons with a Focus on Amenities," Review of Regional Studies, 37, 303-343.

Julien, Pierre-Andrá. (2007) A Theory of Local Entrepreneurship in the Knowledge Economy, Cheltenham, UK: Edward Elgar.

Keeble, David, Sheila Walker, and Mark Robson. (1993) New Firm Formation and Small Business Grow the Spatial and Temporal Variations and Determinants in the United Kingdom. Employment Department: London.

LeSage James P. (2004) “A Family of Geographically Weighted Regression Models," In Luc Anselin, Raymond J.G.M. Florax and Serge J. Rey (eds.), Advances in Spatial Econometrics: Methodology, Tools and Applications. Springer: New York, pp. 241-264.

Levine, Ross and David Renelt. (1992) "A Sensitivity Analysis of Cross-Country Growth Regressions," American Economic Review, 82, 942-963.

Loveridge, Scott and Denys Nizalov. (2007) "Operationalizing the Entrepreneurial Pipeline Theory: An Empirical Assessment of the Optimal Size Distribution of Local Firms," Economic Development Quarterly, 21, 244-262.

Maskell, Peter and Leïla Kebir. (2006) "What Qualifies as a Cluster Theory?” In Bjorn Asheim, Philip Cooke and Ron Martin (eds.), Clusters and Regional Development: Critical Reflections and Explorations. Routledge: London, pp. 30-49.

Montana, Jennifer P. and Boris Nenide. (2008) "The Evolution of Regional Industry Clusters and Their Implications for Sustainable Economic Development: Two Case Illustrations," Economic Development Quarterly, 22, 290-302

Muske, Glenn and Michael Woods. (2004) "Micro Businesses as an Economic Development Tool: What They Bring and What They Need," Journal of the Community Development Society, 35, 97-116.

Nakaya, Tomoki. (2001) "Local Spatial Interaction Modelling Based on the Geographically Weighted Regression Approach,” GeoJournal, 53, 347-358.

Olberging, Julie C. (2002) "Diving into the Third Waves of Regional Governance and Economic Development Strategies: A Study of Regional Partnerships for Economic Development in US Metropolitan Areas,” Economic Development Quarterly, 16, 251-272.

Ozawa, Terutomo. (2000) "Small- and Medium-sized MNCs, Industrial Clusters and Globalization: the Japanese Experience," In Neil Hood and Steven Young (eds.), The 
Globalization of Multinational Enterprise Activity and Economic Development. St. Martin Press: New York, pp. 225-248.

Pace, R. Kelley and James P. LeSage. (2004) "Spatial Autoregressive Local Estimation," In J. Mur Getiz and Harold Zoller (eds.), Spatial Econometrics and Spatial Statistics. Palgrave: New York, pp. 31-51.

Pack, Howard. (1994) "Endogenous Growth Theory: Intellectual Appeal and Empirical Shortcomings," Journal of Economic Perspectives, 8, 55-72.

Páez, Antonio, Takashi Uchida, and Kazuaki Miyamoto. (2002a) “A General Framework for Estimation and Inference of Geographically Weighted Regression Models: 1. LocationSpecific Kernel Bandwidths and a Test for Locational Heterogeneity," Environment and Planning A, 34, 733-754.

(2002b) "A General Framework for Estimation and Inference of Geographically Weighted Regression Models: 2. Spatial Association and Model Specification Tests," Environment and Planning A, 34, 883-904

Partridge, Mark and Dan Rickman. (2006) The Geography of American Poverty: Is There a Role for Place Based Policy? Kalamazoo, MI: W.E. Upjohn Employment Institute.

(2007) "Persistent Pockets of Extreme American Poverty and Job Growth: Is There a Place-Based Policy Role?," Journal of Agricultural and Resource Economics, 32, 201224.

Partridge, Mark, Dan Rickman, Kamar Ali, and Susan Olfert (2008) "The Geographic Diversity of U.S. Nonmetropolitan Growth Dynamics: A Geographically Weighted Regression Approach," Land Economics, 84, 241-266.

Pitelis, Christos and Anastasia Pseirdis. (2006) "A Conceptual Framework for Firm Cooperation and Clusters and Their Impact on Productivity," In Christos Pitelis, Roger Sugden and James R. Wilsom, eds, Clusters and Globalization. Northhampton, MA: Edward Elgar, pp. 17-60.

Porter, Michael E. (1990) The Competitive Advantage of Nations. The Free Press: New York.

(1996) "Competitive Advantage, Agglomeration Economies, and Regional Policy," International Regional Science Review, 19, 85-90.

. (1998a) "Clusters and the New Economics of Competition," Harvard Business Review, 76(6), 77-90.

. (1998b) On Competition. Harvard Business School Press: Cambridge, MA.

(2000) "Location, Competition, and Economic Development: Local Clusters in a Global Economy," Economic Development Quarterly, 14, 15-34.

Putnam, Robert D. (2000) Bowling Alone: The Collapse and Revival of American Community. Simon and Schuster: New York.

Quintana, Miriam and Valeria Pulignano. (2006) "Clustering of Productive Activities: A Terrain for Employment Relations," In Christos Pitelis, Roger Sugden, and James R. Wilsom (eds.), Clusters and Globalisation. Edward Elgar: Northhampton, MA, pp. 196-214.

(C) Southern Regional Science Association 2011. 
Robbins, D. Keith, Louis J. Pantuosco, Darrell F. Parker, and Barbara K. Fuller. (2000) “An Empirical Assessment of the Contribution of Small Business Employment to U.S. State Economic Performance," Small Business Economics, 15, 293-302.

Rubin, Herbert. (1988) "Shoot Anything that Flies; Claim Anything that Falls," Economic Development Quarterly, 2, 236-251.

Sacchetti, Silvia and Philip R. Tomlinson. (2006) "Globalization, Governance and Clusters: North Staffordshire Ceramic and Prato Textile Industries," In Christos Pitelis, Roger Sugden, and James R. Wilsom (eds.), Clusters and Globalisation. Edward Elgar: Northhampton, MA, pp. 232-257.

Sala-i-Martin, Xavier X. (1997) "I Just Ran Two Million Regressions," American Economic Review, 87, 178-183.

Schultz, T. Paul. (1999) "Health and Schooling Investments in Africa," Journal of Economic Growth, 13, 67-88.

Schumpeter, Joseph A. (1942) Capitalism, Socialism \& Democracy. Harper \& Row: New York. . (1961) The Theory of Economic Development. Harvard University Press: Cambridge, MA.

Shaffer, Ron. (2001) "Building a National Rural Policy and the National Rural Development Partnership," Journal of Regional Analysis and Policy, 21, 77-91.

Shaffer, Ron, Steven C. Deller, and David W. Marcouiller. (2004). Community Economics: Linking Theory and Practice. Blackwell Professional Publishing: Oxford.

. (2006) "Rethinking Community Economic Development," Economic Development Quarterly, 20, 59-74

Shaffer, Sherrill. (2002). "Firm Size and Economic Growth," Economic Letters, 76, 195-203. (2006) "Establishment Size and Local Employment Growth," Small Business Economics, $26,439-454$.

Steinnes, Dennis and William Fisher. (1974) "An Econometric Model of Intraurban Location," Journal of Regional Science, 14, 65-80.

Thisse, Jacques-François and Masahisa Fujita. (2002) Economics of Agglomeration. Cambridge University Press: Cambridge, UK.

U.S. Small Business Administration. (1983, 1987) The State of Small Business: A Report to the President. U.S. Government Printing Office: Washington DC.

Wennberg, Karl and Göran Lindqvist. (2010) "The Effects of Clusters on the Survival and Performance of New Firms," Small Business Economics, 34, 221-241.

Wheeler, David and Michael Tiefelsdorf. (2005) "Multicollinearity and Correlation Among Local Regression Coefficients in Geographically Weighted Regression," Journal of Geographical Systems, 7, 161-187.

Woodward, Douglas P. and Paulo Guimarães. (2009) "Porter's Cluster Strategy and Industrial Targeting," In Stephan J. Goetz, Steven C. Deller, and Thomas Harris (eds.), Targeting Regional Economic Development. Routledge Publishing: London, pp. 68-83. 